\title{
Effect of Designing Nursing Teaching Protocol on Patients Undergoing Chemotherapy to Minimize Complications of Neutropenia
}

\author{
Heba Sayed Mohammed ${ }^{1}$, Shalabia El-Sayed Abozead ${ }^{2}$, Salah Mabrouk Khallaf ${ }^{3}$ \& Asmaa Sayed Abd \\ Almageed 4 . \\ B.Sc. Nursing, Faculty of Nursing, South Egypt Cancer Institute, Assiut University, Assiut, Egypt. \\ Professor of Medical Surgical Nursing, Faculty of Nursing, Assiut University, Assiut, Egypt. \\ Lecturer of Medical Oncology, South Egypt Cancer Institute, Assiut University, Assiut, Egypt. \\ Lecturer of Medical Surgical Nursing, Faculty of Nursing, Assiut University, Assiut, Egypt.
}

\begin{abstract}
Background Patients undergoing chemotherapy are at risk of developing neutropenia that may cause lifethreatening infections and death. Aim: Evaluate effect of designing nursing teaching protocol on patients undergoing chemotherapy to minimize complications of neutropenia. Design: A Pre and Post test research design was utilized. Sample: sixty adult patients undergoing chemotherapy both males and females. Setting: The study was carried out in the internal medical oncology departments and intensive care unit at South Egypt Cancer Institute. Tools: An interview questionnaire sheet for the patient, A designed nursing teaching protocol for patients undergoing chemotherapy to minimize complications of neutropenia and patient's assessment sheet for complications of neutropenia. Results: There were highly statistically significant differences between "pre and post" application of the designed nursing teaching protocol in both all knowledge items and complications of neutropenia $\mathrm{P}<0.001$. Conclusion: there were highly statistically significant differences between studied patients "pre and post" application of the designed nursing teaching protocol regarding total knowledge and complications of neutropenia. Recommendation: Tangible tools and education of patients, families and healthcare workers are keys to speedy recognition of potentially life-threatening symptoms associated with neutropenia.
\end{abstract}

\section{Keywords: Chemotherapy, Complications, Neutropenia \& Nursing Teaching Protocol.}

\section{Introduction}

Patients undergoing myelo-suppressive chemotherapy are at risk of developing neutropenia that meant as an absolute neutrophil count less than $500 / \mathrm{mm}^{3}$, a problem which may lead to lifethreatening infections that may quickly lead to sepsis and death. (Hawley et al., 2011) \& (Hashiguchi et al., 2015)

The febrile neutropenia $(\mathrm{FN})$ consider the main common cause of morbidity, so immediate treatment and dose reduction in patients undergoing chemotherapy is very important. (Weycker et al., 2014) \& (Supportive \& Board 2016).

A decrease of elements of the immune system in many patients experience cancer that make them more susceptible to many infections as regarding to the kind and intensity of chemotherapy received and other risk factors. Neutropenia considered an oncology emergency and can cause adverse consequences such as serious infection complications and death. (Villafuerte et al., 2014) \& (Rasmy et al., 2016).

Therapeutic treatment is very important to enhance the immune-deficient body target an active infection efficiently. When febrile neutropenia occurs, it is important to initial treatment with broad-spectrum antibiotics by hospitalize patient as fast as possible provide rapidly management. Until the neutrophils count return to the normal level, the patients should kept under close observation. (Lustberg., 2012)

Oncology nurses should identify patients at risk for developing neutropenia and monitor patients who already have abnormal neutrophil counts for better initiation of interventions to enhance patients' management with cancer receiving chemotherapy. (Ropka \& Padilla, 2007) \& (Teleb \& Mohamed, 2016)

\section{Significance of the study}

From the researchers observation that patient's knowledge about neutropenia was inadequate and patients are in need to know more about neutropenia and its effect that may be life-threatening infections, sepsis and death. About (4300) new cases according to South Egypt Cancer Institute record in a year of (2017), therefor this study considered the first, which produced an outline to nursing care for patients undergoing chemotherapy to minimize complications of neutropenia in a form of designed nursing teaching protocol that can have the effect on life and death in this geographical location. 


\section{Aim of the study}

To evaluate effect of designing nursing teaching protocol on patients undergoing chemotherapy to minimize complications of neutropenia through the following:

1. Assess patient`s knowledge about neutropenia.

2. Design a nursing teaching protocol for patients undergoing chemotherapy and have neutropenia.

3. Evaluate effect of designing nursing teaching protocol among the patients undergoing chemotherapy minimizing complications of neutropenia.

\section{Subjects \& Methods \\ Research design}

We used in this study Pre \& Post test of research design.

\section{Setting}

At South Egypt Cancer Institute the study was conducted in internal medical oncology department and intensive care unit.

\section{Variables}

- The independent variable is the designed nursing teaching protocol.

- Patient`s knowledge and neutropenia complications considered the dependent variables

\section{Subjects}

The study sample (convenient sample) consisted of sixty adult patients, mean age ranged between (1865) years, both males and females undergoing chemotherapy and consented to participate in the study. Study period four months from December, 2016 to April, 2017.

\section{Study tools}

Tool (I): An interview questionnaire sheet, it included three parts

\section{Part (1): Demographic and medical data:}

The researchers formed this part based on literature review by the researchers and it included the following:

- Patients' demographic data: included age, sex, level of education, marital status, type of employment, residence and smoking).

- Medical data about patients which include of type of cancer, stage of cancer, presence of chronic illness, medication use and investigation of the studied patients. These are client-related risk factors for developing neutropenia.

\section{Part (2): ECOG performance status}

It was developed by the Eastern Cooperative Oncology Group Oken et al., (1982). It described a patient's functioning levels in terms of their ability to care for them self, daily activity, and physical ability. It was contained 6 grades classified as following:

\begin{tabular}{|c|l|}
\hline $\begin{array}{c}\text { Grade } \\
(\mathbf{0})\end{array}$ & $\begin{array}{l}\text { Fully active, able to carry on all } \\
\text { pre-disease performance without } \\
\text { restriction, }\end{array}$ \\
\hline $\begin{array}{c}\text { Grade } \\
(\mathbf{1})\end{array}$ & $\begin{array}{l}\text { Restricted in physically strenuous } \\
\text { activity but ambulatory and able to } \\
\text { carry out work of a light or } \\
\text { sedentary nature, light house } \\
\text { work, office work. }\end{array}$ \\
\hline $\begin{array}{c}\text { Grade } \\
(\mathbf{2})\end{array}$ & $\begin{array}{l}\text { Ambulatory and capable of all self } \\
\text { care but unable to carry out any } \\
\text { work activities; up and about more } \\
\text { than 50\% of waking hours. }\end{array}$ \\
\hline $\begin{array}{c}\text { Grade } \\
(3)\end{array}$ & $\begin{array}{l}\text { Capable of only limited self care; } \\
\text { confined to bed or chair more than } \\
50 \% \text { of waking hours. }\end{array}$ \\
\hline $\begin{array}{c}\text { Grade } \\
(\mathbf{4})\end{array}$ & $\begin{array}{l}\text { Completely disabled; cannot carry } \\
\text { on any self care; totally confined } \\
\text { to bed or chair. }\end{array}$ \\
\hline $\begin{array}{c}\text { Grade } \\
(\mathbf{5})\end{array}$ & \begin{tabular}{l} 
Death \\
\hline
\end{tabular} \\
\hline
\end{tabular}

Part (3-A): Patients' knowledge about neutropenia Based on national and international literature to identify patients' knowledge about neutropenia, it was formed by the researchers. It included 12 multiple choices questions for assessing the patient's knowledge level on the prevention of neutropenia containing information about white blood cells, prevention of infection in environmental factors, dietary factors, personal hygiene, and management of neutropenic infection. These questions were developed related to the content of the education program.

\section{Scoring system}

Total number of questions was twelve, each question contained five responses (from A to E), and the patient chooses the answer. The total score of patients' knowledge questionnaire sheet was 60 degrees:

- More than 50\% means satisfactory.

- Less than 50\% means unsatisfactory.

Part (3-B): Designed nursing teaching protocol

The researchers developed this protocol based on patient's knowledge assessment and after current national and international literature reviewing. It aimed to supply the patients with adequate knowledge about neutropenia care; introduction, definition, causes, signs and symptoms, diagnostic studies, medical management of neutropenia and the designed nursing teaching protocol for neutropenia patients.

Tool (II): Patient's complications assessment sheet:

This sheet aimed to assess complications of patients undergoing chemotherapy and complains from 
neutropenia pre and after applying of the designed nursing teaching protocol.

It consists two main parts

Part (1): Scale for grades severity of neutropenia (According to National Cancer Institute (NCI, 2010)

It consisted of the level score of severity of neutropenia and febrile neutropenia from grade ( 1 to 5);

\begin{tabular}{|l|l|}
\hline Grade & $\begin{array}{l}\text { Mild, with mild or no symptoms } \\
\text { and no interventions required } \\
\text { when (Neutrophils less than lower } \\
\left.\text { limit of normal to } 1500 / \mathrm{mm}^{3}\right),\end{array}$ \\
\hline $\begin{array}{l}\text { Grade } \\
(\mathbf{2})\end{array}$ & $\begin{array}{l}\text { Moderate; minimal intervention } \\
\text { indicated and some limitation of } \\
\text { activities when (Neutrophils less } \\
\left.\text { than } 1500 / \mathrm{mm}^{3} \text { to } 1000 / \mathrm{mm}^{3}\right),\end{array}$ \\
\hline $\begin{array}{l}\text { Grade } \\
\mathbf{( 3 )}\end{array}$ & $\begin{array}{l}\text { Severe but not life threatening; } \\
\text { hospitalization required and } \\
\text { limitation of patient's ability to } \\
\text { care for him/herself when } \\
\text { (Neutrophils less than 1500/mm }\end{array}$ \\
to $\left.1000 / \mathrm{mm}^{3}\right)$,
\end{tabular}

Part (2): The complication's assessment sheet: According to Common Terminology Criteria for Adverse Events (CTCAE) Version 4.0, (2010)

\begin{tabular}{|l|l|l|l|l|l|}
\hline \multicolumn{5}{|c|}{ Infections and infestations } \\
\hline \multicolumn{5}{|c|}{ Grade } \\
\hline Adverse Event & 1 & 2 & 3 & 4 & 5 \\
\hline $\begin{array}{l}\text { Abdominal } \\
\text { infection }\end{array}$ & & & & & \\
\hline Anorectal infection & & & & & \\
\hline Appendicitis & & & & & \\
\hline Bladder infection & & & & & \\
\hline Bronchial infection & & & & & \\
\hline $\begin{array}{l}\text { Catheter related } \\
\text { infection }\end{array}$ & & & & & \\
\hline $\begin{array}{l}\text { Conjunctivitis } \\
\text { infective }\end{array}$ & & & & & \\
\hline $\begin{array}{l}\text { Enterocolitis } \\
\text { infectious }\end{array}$ & & & & & \\
\hline $\begin{array}{l}\text { Esophageal } \\
\text { infection }\end{array}$ & & & & & \\
\hline Eye infection & & & & & \\
\hline $\begin{array}{l}\text { Gallbladder } \\
\text { infection }\end{array}$ & & & & & \\
\hline Gum infection & & & & & \\
\hline Lung infection & & & & & \\
\hline
\end{tabular}

\begin{tabular}{|l|l|l|l|l|l|}
\hline Meningitis & & & & & \\
\hline Mucosal infection & & & & & \\
\hline Otitis media & & & & & \\
\hline Pharyngitis & & & & & \\
\hline Phlebitis infective & & & & & \\
\hline Pleural infection & & & & & \\
\hline Prostate infection & & & & & \\
\hline Rash pustular & & & & & \\
\hline Rhinitis infective & & & & & \\
\hline $\begin{array}{l}\text { Salivary gland } \\
\text { infection }\end{array}$ & & & & & \\
\hline Sepsis & & & & & \\
\hline Sinusitis & & & & & \\
\hline Skin infection & & & & & \\
\hline $\begin{array}{l}\text { Small intestine } \\
\text { infection }\end{array}$ & & & & & \\
\hline $\begin{array}{l}\text { Soft tissue } \\
\text { infection }\end{array}$ & & & & & \\
\hline $\begin{array}{l}\text { Stoma site } \\
\text { infection }\end{array}$ & & & & & \\
\hline Tooth infection & & & & & \\
\hline $\begin{array}{l}\text { Upper respiratory } \\
\text { infection }\end{array}$ & & & & & \\
\hline $\begin{array}{l}\text { Urinary tract } \\
\text { infection }\end{array}$ & & & & & \\
\hline Uterine infection & & & & & \\
\hline Vaginal infection & & & & & \\
\hline Wound infection & & & & & \\
\hline $\begin{array}{l}\text { Infections and } \\
\text { infestations - } \\
\text { Other, specify }\end{array}$ & & & & & \\
\hline
\end{tabular}

Grade refers to the severity of the Adverse Event (AE). The CTCAE displays Grades 1 through 5 with unique clinical descriptions of severity for each $\mathrm{AE}$ based on this general guideline:

Grade (1): Mild; asymptomatic, intervention not indicated.

Grade (2): Moderate; local or noninvasive intervention indicated.

Grade(3):Severe or medically significant but not immediately life threatening; hospitalization or prolongation of hospitalization indicated.

Grade (4): Life-threatening consequences; urgent intervention indicated.

Grade (5): Death related to AE.

Ethical considerations

An official permission to conduct the study was acquired by the researchers from the South Egypt Cancer Institute' Dean. The reason of this research was explained for each patient. The researcher accentuated that the participation is deliberate also confidentially and anonymity of patients were achieved by coding all patient's data, and protection of the patient from hazard was achieved. A verbal 
consent was acquired from every patient preceding his/her contribution in the present study. Confidentiality of any obtained information was secured.

\section{Technique for data collection:}

A review of current and past, local and international related literature in the various aspects of the problem using books, articles, periodicals, and magazines was done.

\section{Content validity}

Content validity was established by panel of 5 expertises: 3 teaching staff of Medical Surgical Nursing, Faculty of Nursing, at Assiut University, and 2 Lecturers of Medical Oncology in South Egypt Cancer Institute) who reviewed the tools of data collection for clarity, relevance, comprehensiveness, understanding, applicability and easiness, minor modifications are required.

\section{Pilot study}

A pilot study was carried out on $10 \%(n=6)$ of the sample in the selected setting to evaluate the applicability and clarity of the tools; those patients were included in the main study if no modification. It had also provided an estimation of the time needed to fill out the tools.

\section{Procedure}

Once permission was granted to proceed with the proposed study, the researcher initiated data collection.

- At initial interview, the researcher introduced herself to initiate communication.

- Verbal consent was obtained from each patient prior to his/her contribution in the present study.
- The researcher explained nature and purpose of the research to the selected patients who participated in the study.

- Each patient involved in the study was assessed for his /her knowledge pre test (tool I) after admission, the tools filled through interviewing. The study was carried out at morning, and at after noon shifts.

- The researcher assessed patients who participated in the study for complications of neutropenia (tool II).

- The application of the designed nursing teaching protocol (tool I) was performed by the researcher then by patients; the researcher prepared the teaching aids and media (pictures, handout). Each patient or his/her relatives obtained a copy of the designed nursing teaching protocol. Data were collected through the period from December, 2016 to April, 2017.

- Evaluate applying of the designed nursing teaching protocol on patient's knowledge before discharge using (tool I). As well as the researcher filled the patient's complications assessment sheet (tool II).

\section{Statistical design}

The data analysis was carried out using soft wear package computer program SPSS (version, 23) the collected data were tabulated and analyzed by using frequency, percentage, distribution, range and standard deviation. The level of statistically significant was considered at $\mathrm{p}<0.05$. Independent $\mathrm{T}$ test, chi square were used to compare between pre and after applied of nursing teaching protocol regarded to investigation of studied patients.

\section{Results}

Table (1): Distribution of socio-demographic data for studied patients $(n=60)$

\begin{tabular}{|c|c|c|}
\hline \multicolumn{1}{|c|}{ Variables } & N. & $\%$ \\
\hline Age by years: & & 20.0 \\
\hline$-18<29$ & 12 & 25.0 \\
\hline$-29<40$ & 15 & 21.7 \\
\hline$-40<50$ & 13 & 33.3 \\
\hline$-\quad 50$ and more & 20 & \\
\hline Mean+SD & \multicolumn{1}{|c|}{$41.78+14.59$} \\
\hline Sex: & 21 & 35.0 \\
\hline$-\quad$ Male & 39 & 65.0 \\
\hline$-\quad$ Female & & 26.7 \\
\hline Marital status: & 16 & 56.7 \\
\hline$-\quad$ Single & 34 & 6.7 \\
\hline$-\quad$ Married & 4 & 10.0 \\
\hline$-\quad$ Divorced & 6 & 25.0 \\
\hline$-\quad$ Widowed & & 8.3 \\
\hline Level of education: & 15 & \\
\hline$-\quad$ Illiterate & 5 & \\
\hline$-\quad$ Primary school & & \\
\hline
\end{tabular}




\begin{tabular}{|c|c|c|}
\hline \multicolumn{1}{|c|}{ Variables } & N. & \% \\
\hline$-\quad$ Secondary education & 28 & 46.7 \\
\hline bachelor's degree or above & 12 & 20.0 \\
\hline Types of Employment : & & \\
\hline$-\quad$ Unemployed & 42 & 70.0 \\
\hline$-\quad$ Employed & 18 & 30.0 \\
\hline Type of residence: & & \\
\hline$-\quad$ Rural & 49 & 81.7 \\
\hline$-\quad$ Urban & 11 & 18.3 \\
\hline Smoking: & 7 & 11.7 \\
\hline$-\quad$ Smokers & 53 & 88.3 \\
\hline$-\quad$ Non smokers & & \\
\hline
\end{tabular}

Table (2): Percentage distribution of the studied patients regarding their medical data $(n=60)$.

\begin{tabular}{|c|c|c|}
\hline Variables & $\mathbf{N}$. & $\%$ \\
\hline \multicolumn{3}{|l|}{ Type of cancer } \\
\hline - $\quad$ Acute myeloid leukemia & 21 & 35.0 \\
\hline - $\quad$ Cancer ovary & 6 & 10.0 \\
\hline - $\quad$ Ewing's sarcoma & 1 & 1.7 \\
\hline - $\quad$ Multiple myeloma & 2 & 3.3 \\
\hline - $\quad$ Acute lymphatic leukemia & 6 & 10.0 \\
\hline - $\quad$ large retroperitoneal mass & 1 & 1.7 \\
\hline - $\quad$ Relapsed all & 4 & 6.7 \\
\hline - $\quad$ Myeloid fibrosis & 1 & 1.7 \\
\hline - $\quad$ Breast cancer & 5 & 8.3 \\
\hline - Cancer colon & 4 & 6.7 \\
\hline - $\quad$ Cancer lung & 3 & 5.0 \\
\hline$-\quad$ NHL & 4 & 6.7 \\
\hline - $\quad$ Cancer bladder & 2 & 3.3 \\
\hline \multicolumn{3}{|l|}{ Stages of cancers } \\
\hline - $\quad$ Stage 1 & 1 & 1.7 \\
\hline$-\quad$ Stage 2 & 1 & 1.7 \\
\hline$-\quad$ Stage 3 & 10 & 16.7 \\
\hline$-\quad$ Stage 4 & 13 & 21.7 \\
\hline \multicolumn{3}{|l|}{ Presence of chronic illness } \\
\hline \multicolumn{3}{|l|}{ Liver disease } \\
\hline - Yes & 5 & 8.3 \\
\hline$-\quad$ No & 55 & 91.7 \\
\hline \multicolumn{3}{|l|}{ Renal disease } \\
\hline$-\quad$ Yes & 1 & 1.7 \\
\hline$-\quad$ No & 59 & 98.3 \\
\hline \multicolumn{3}{|l|}{ Cardiovascular disease } \\
\hline - Yes & 12 & 20.0 \\
\hline$-\quad$ No & 48 & 80.0 \\
\hline \multicolumn{3}{|l|}{ Present of open wound } \\
\hline - Yes & 2 & 3.3 \\
\hline$-\quad$ No & 58 & 96.7 \\
\hline \multicolumn{3}{|l|}{ Previous radiation therapy } \\
\hline$-\quad$ Yes & - & - \\
\hline$-\quad$ No & 60 & 100.0 \\
\hline
\end{tabular}




\begin{tabular}{|c|c|c|}
\hline Variables & $\mathbf{N}$. & $\%$ \\
\hline $\begin{array}{c}\text { Antibiotic } \\
-\quad \\
-\quad \text { No }\end{array}$ & $\begin{array}{l}34 \\
26\end{array}$ & $\begin{array}{l}56.7 \\
43.3\end{array}$ \\
\hline $\begin{array}{c}\text { Anti-fungal } \\
-\quad \text { Yes } \\
-\quad \text { No }\end{array}$ & $\begin{array}{l}28 \\
32\end{array}$ & $\begin{array}{l}46.6 \\
53.3\end{array}$ \\
\hline $\begin{array}{c}\text { Antibiotic and anti-fungal } \\
-\quad \text { Yes } \\
-\quad \text { No } \\
\end{array}$ & $\begin{array}{l}26 \\
34 \\
\end{array}$ & $\begin{array}{l}43.3 \\
56.7 \\
\end{array}$ \\
\hline $\begin{array}{cc}\text { G-CSF } & \\
- & \text { Yes } \\
- & \text { No }\end{array}$ & $\begin{array}{l}35 \\
25\end{array}$ & $\begin{array}{l}58.3 \\
41.7\end{array}$ \\
\hline
\end{tabular}

(GCSF): Granulocyte colony stimulating factor

Table (3): Percentage distribution for medical data of the studied patients regarding to ECOG performance status $(n=60)$.

\begin{tabular}{|c|c|c|c|c|c|c|c|c|c|c|c|c|}
\hline \multirow[t]{2}{*}{ Variable } & \multicolumn{2}{|c|}{$\begin{array}{c}\text { Grade } \\
0\end{array}$} & \multicolumn{2}{|c|}{$\begin{array}{c}\text { Grade } \\
1\end{array}$} & \multicolumn{2}{|c|}{$\begin{array}{c}\text { Grade } \\
2\end{array}$} & \multicolumn{2}{|c|}{$\begin{array}{c}\text { Grade } \\
\mathbf{3}\end{array}$} & \multicolumn{2}{|c|}{$\begin{array}{c}\text { Grade } \\
4\end{array}$} & \multicolumn{2}{|c|}{ Grade5 } \\
\hline & $\mathbf{N}$ & $\%$ & $\mathrm{~N}$ & $\%$ & $\mathrm{~N}$ & $\%$ & $\mathrm{~N}$ & $\%$ & $\mathbf{N}$ & $\%$ & $\mathbf{N}$ & $\%$ \\
\hline $\begin{array}{l}\text { Full active, able to carry on } \\
\text { all pre-disease performance } \\
\text { without restriction. }\end{array}$ & 36 & 60.0 & - & - & - & - & & & & & & \\
\hline $\begin{array}{l}\text { Restricted in physically } \\
\text { strenuous activity but } \\
\text { ambulatory and able to carry } \\
\text { out work of a light or } \\
\text { sedentary nature( light house } \\
\text { work, office work) }\end{array}$ & - & - & 10 & 16.7 & & & & & & & & \\
\hline $\begin{array}{l}\text { Ambulatory and capable of } \\
\text { all self-care but unable to } \\
\text { carry out any work activities } \\
\text {,up and about more than } \\
50 \% \text { of waking hours }\end{array}$ & & & & & 3 & 5.0 & & & & & & \\
\hline $\begin{array}{l}\text { Capable of only limited self } \\
\text {-care ,confined to bed or } \\
\text { chair more than } 50 \% \text { of } \\
\text { waking hours }\end{array}$ & & & & & & & 8 & 13.3 & & & & \\
\hline $\begin{array}{l}\text { Completely disabled ,cannot } \\
\text { carry on any self-care: } \\
\text { totally confined to bed or } \\
\text { chair }\end{array}$ & & & & & & & & & 3 & 5.0 & & \\
\hline Dead & & & & & & & & & & & 0 & 0 \\
\hline
\end{tabular}

(ECOG): Developed by the Eastern Cooperative Oncology Group

Table (4): Comparison between pre and post application of the designed nursing teaching protocol regarding studied sample`s knowledge about neutropenia $(n=60)$

\begin{tabular}{|c|c|c|c|c|c|}
\hline \multirow{2}{*}{ Variable } & \multicolumn{2}{|c|}{ Pretest } & \multicolumn{2}{|c|}{ Posttest } & \multirow{2}{*}{ P.v } \\
\hline & N. & $\%$ & N. & $\%$ & \\
\hline $\begin{array}{c}\text { Function of white blood cells: } \\
-\quad \text { Transport oxygen and nutrient } \\
-\quad \text { Fight infection }\end{array}$ & $\begin{array}{l}1 \\
1\end{array}$ & $\begin{array}{l}1.7 \\
1.7\end{array}$ & $\begin{array}{c}- \\
54\end{array}$ & 100 & $0.00 * *$ \\
\hline
\end{tabular}




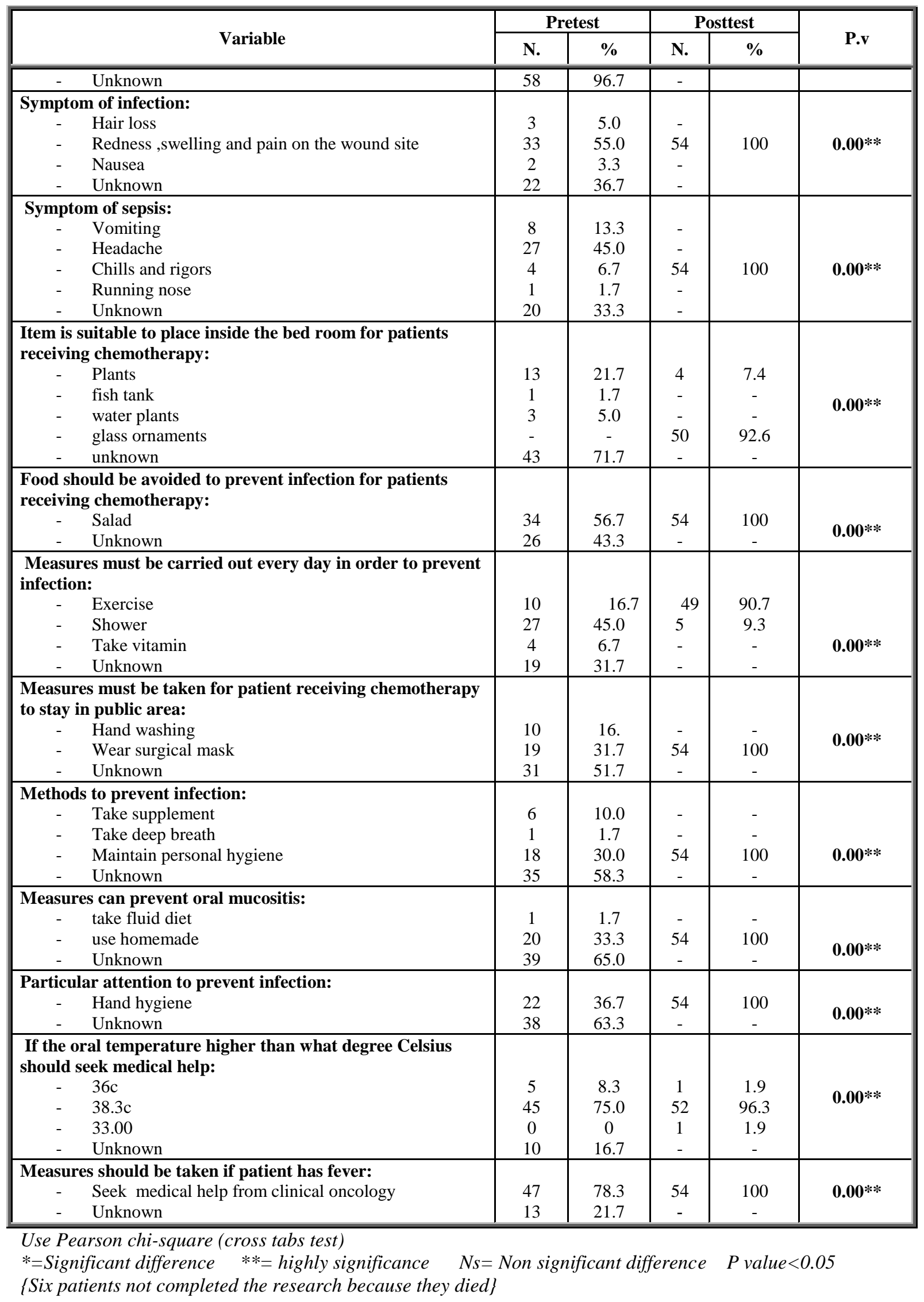


Table (5): Relation between demographic data and studied patient's knowledge about neutropenia pre and post application designing nursing teaching protocol.

\begin{tabular}{|c|c|c|c|c|c|c|c|c|c|c|}
\hline \multirow{2}{*}{ Variable } & \multicolumn{4}{|c|}{ Pretest } & \multicolumn{4}{|c|}{ Posttest } & \multirow[t]{3}{*}{ P.v1 } & \multirow[t]{3}{*}{ P.v2 } \\
\hline & \multicolumn{2}{|c|}{ Satisfactory } & \multicolumn{2}{|c|}{ Unsatisfactory } & \multicolumn{2}{|c|}{ Satisfactory } & \multicolumn{2}{|c|}{ Unsatisfactory } & & \\
\hline age by years & N. & $\%$ & N. & $\%$ & N. & $\%$ & N. & $\%$ & & \\
\hline $\begin{array}{ll}- & 18-28 y \\
- & 29-39 y \\
- & 40-50 y \\
- & >\text { than } 50 \\
\end{array}$ & $\begin{array}{l}2 \\
1 \\
2 \\
0\end{array}$ & $\begin{array}{c}3.3 \\
1.7 \\
3.3 \\
0\end{array}$ & $\begin{array}{l}10 \\
14 \\
11 \\
20\end{array}$ & $\begin{array}{l}16.7 \\
23.3 \\
18.3 \\
33.3\end{array}$ & $\begin{array}{l}10 \\
11 \\
11 \\
19\end{array}$ & $\begin{array}{l}18.5 \\
20.3 \\
20.3 \\
35.9\end{array}$ & $\begin{array}{l}0 \\
2 \\
1 \\
0\end{array}$ & $\begin{array}{c}0 \\
3.7 \\
1.85 \\
0\end{array}$ & 0.23 & 0.28 \\
\hline $\begin{aligned} & \text { sex } \\
&- \text { Male } \\
&- \text { Female } \\
&\end{aligned}$ & $\begin{array}{l}3 \\
2\end{array}$ & $\begin{array}{l}5.0 \\
3.3\end{array}$ & $\begin{array}{l}18 \\
37\end{array}$ & $\begin{array}{l}30.0 \\
61.7\end{array}$ & $\begin{array}{l}17 \\
34\end{array}$ & $\begin{array}{l}31.5 \\
62.9\end{array}$ & $\begin{array}{l}2 \\
1\end{array}$ & $\begin{array}{c}3.7 \\
1.85\end{array}$ & 0.28 & 0.22 \\
\hline $\begin{array}{cl}\text { marital status } \\
- & \text { single } \\
- & \text { married } \\
- & \text { separated } \\
- & \text { widowed }\end{array}$ & $\begin{array}{l}2 \\
3 \\
0 \\
0\end{array}$ & $\begin{array}{c}3.3 \\
5.0 \\
0 \\
0\end{array}$ & $\begin{array}{c}14 \\
31 \\
4 \\
6\end{array}$ & $\begin{array}{c}23.3 \\
51.7 \\
6.7 \\
10.0\end{array}$ & $\begin{array}{c}15 \\
28 \\
3 \\
5\end{array}$ & $\begin{array}{c}27.8 \\
51.8 \\
5.6 \\
9.25\end{array}$ & $\begin{array}{l}0 \\
3 \\
0 \\
0\end{array}$ & $\begin{array}{c}0 \\
5.6 \\
0 \\
0\end{array}$ & 0.67 & 0.86 \\
\hline \begin{tabular}{|cl} 
Type of employment \\
- & housewife \\
- & unemploye \\
- & profession \\
- & clerk \\
- & other
\end{tabular} & $\begin{array}{l}1 \\
2 \\
1 \\
1 \\
0\end{array}$ & $\begin{array}{l}1.7 \\
3.3 \\
1.7 \\
1.7 \\
0.0\end{array}$ & $\begin{array}{c}26 \\
13 \\
5 \\
6 \\
5\end{array}$ & $\begin{array}{c}43.3 \\
21.7 \\
8.3 \\
10.0 \\
8.3\end{array}$ & $\begin{array}{c}23 \\
15 \\
2 \\
6 \\
5\end{array}$ & $\begin{array}{c}42.6 \\
27.8 \\
3.7 \\
11.1 \\
9.25\end{array}$ & $\begin{array}{l}1 \\
0 \\
2 \\
0 \\
0\end{array}$ & $\begin{array}{c}1.85 \\
0 \\
3.7 \\
0 \\
0\end{array}$ & 0.002 & 0.63 \\
\hline \multicolumn{11}{|l|}{ Education level } \\
\hline - non schooling & 0 & 0 & 15 & 25.0 & 14 & 25.9 & 0 & 0 & \multirow{4}{*}{0.26} & \multirow{4}{*}{0.48} \\
\hline - primary school & 1 & 1.7 & 4 & 6.7 & 5 & 9.25 & 0 & 0 & & \\
\hline - secondary school & 3 & 5.0 & 25 & 41.7 & 21 & 38.9 & 3 & 5.6 & & \\
\hline - bachelor's degree & 1 & 1.7 & 11 & 18.3 & 11 & 20.4 & 0 & 0 & & \\
\hline
\end{tabular}

Use Pearson chi-square (cross tabs test). $*=$ Significant difference $\quad * *=$ highly significance $\quad N s=$ Non significant difference $P$ value $<0.05$

Table (6): Comparison between total knowledge scores pre and post application of the designed nursing teaching protocol.

\begin{tabular}{|c|c|c|c|c|c|}
\hline \multirow{2}{*}{ Variable } & \multicolumn{2}{|c|}{ Pretest } & \multicolumn{2}{|c|}{ Posttest } & P.v \\
\hline & N. & $\%$ & N. & $\%$ & \multirow{3}{*}{$0.00 * *$} \\
\hline $\begin{array}{l}\text { Satisfactory knowledge } \\
\text { (More than 50\%) }\end{array}$ & 5 & 8.3 & 51 & 94.4 & \\
\hline - $\quad$ Unsatisfactory knowledge (Less than 50\%) & 55 & 91.7 & 3 & 5.6 & \\
\hline
\end{tabular}


Table (7): Frequency distribution between pre, and post application of the designed nursing teaching protocol regarding complications of neutropenia of studied patients $(n=60)$.

\begin{tabular}{|c|c|c|c|c|c|}
\hline \multirow[t]{2}{*}{ Complications } & \multicolumn{2}{|c|}{$\begin{array}{l}\text { Pretest } \\
\text { Grade } 3\end{array}$} & \multicolumn{2}{|c|}{$\begin{array}{l}\text { Posttest } \\
\text { Grade } 1\end{array}$} & \multirow[t]{2}{*}{ p.v } \\
\hline & N. & $\%$ & N. & $\%$ & \\
\hline - $\quad$ Cardiac disorder & 1 & 1.7 & - & - & 0.5 \\
\hline - $\quad$ Ear disorder & 5 & 8.3 & 5 & 9.25 & $0.04 *$ \\
\hline - $\quad$ Endocrine disorder & 1 & 1.7 & 1 & 1.85 & 0.5 \\
\hline - $\quad$ Eye disorder & 2 & 3.3 & 1 & 1.85 & 0.33 \\
\hline - $\quad$ Gastrointestinal disorder & 21 & 35.0 & 19 & 35.18 & $0.00 * *$ \\
\hline - $\quad$ General disorder & 1 & 1.7 & 1 & 1.85 & 0.5 \\
\hline - $\quad$ Hebato biliary disorder & 4 & 6.7 & 3 & 5.6 & $0.02 *$ \\
\hline - $\quad$ Immune disorder & 1 & 1.7 & 1 & 1.85 & 0.5 \\
\hline - $\quad$ Urinary tract infection & 15 & 25.0 & 13 & 24.1 & $0.00 * *$ \\
\hline - $\quad$ Musculoskeletal & 2 & 3.3 & 2 & 3.7 & 0.16 \\
\hline - $\quad$ Renal disorder & 5 & 8.3 & 5 & 9.25 & $0.00 * *$ \\
\hline - $\quad$ Reproductive system & 2 & 3.3 & 2 & 3.7 & 0.16 \\
\hline - $\quad$ Respiratory disorder & 41 & 68.3 & 41 & 75.9 & $0.00 *$ \\
\hline - $\quad$ skin disorder & 4 & 6.7 & 4 & 7.4 & 0.01 \\
\hline - $\quad$ Vascular disorder & 1 & 1.7 & 1 & 1.85 & 0.5 \\
\hline
\end{tabular}

Table (1): Showed that more than half of the studied group were females, married and their ages were 50 years and more $(65.0 \%, 56.7 \%$ and $33.3 \%)$ respectively. The most common level of education of the studied group was secondary school (46.7\%). As regard to type of employment, type of residence and smoking "the majority of the studied group were unemployed, living in rural areas and non-smokers $(70.0 \%, 81.7 \%$ and $88.3 \%)$ respectively.

Table (2): Clarified that the most common type of cancer among the studied group was" Acute Myeloid Leukemia", the most common stage of cancer was stage 4, the most common chronic illness was cardiovascular disease and more than half of the studied group used antibiotics and G-CSF as a treatment at the onset of admission $(35 \%, 21.7 \%$, $20.0 \%, 56.7 \%$ and $58.3 \%$ ) respectively.

Table (3): Represents that more than half of the studied patients located in" Grade 0" of ECOG performance status which presented (Full active, able to carry on all pre-disease performance without restriction).

Table (4): Showed that there were highly statistically significant differences between "pre and post" application of the designed nursing teaching protocol in all knowledge items $\mathrm{P}<0.001$.

Table (5): Shows that pre- application of the designed nursing teaching protocol the majority of the studied patients who were having unsatisfying level of knowledge were female, house wife and older ages. There was a relation between knowledge and type of employment among studied sample.
Table (6): Showed that a highly statistically significant differences between" pre and post" application of the designed nursing teaching protocol regarding total knowledge scores $\mathrm{P} . \mathrm{V}<0.00$.

Table (7): Showed that there were statistically significant differences between the studied patients before and after application of the designed nursing teaching protocol regarding complications of neutropenia, which included (ear disorder, gastrointestinal disorder, urinary tract disorder, renal and respiratory disorder $\mathrm{P}<0.0$.

\section{Discussion \\ I-Socio demographic and medical data \\ Socio demographic data:}

The present study explored the following: more than half of the studied patients were females, married and their ages 50 years and more, they were unemployed and non-smokers and this agreed with Schelenz et al., (2012), Rasmy et al., (2016) \& Gerges, (2018) who explained the variability of the occurrence of febrile neutropenia related to several factors that contained cancer type, chemotherapy regimen, antibiotic treatment, age and sex. So related to the age and sex, the mean age was 63 years and more than half of patients were females. Also, Lyman et al., (2003), Desoky et al., (2014) \& Hussein \& Shehata (2016) reported that ten results of previous studies found advanced age to be most common risk factor for occurrence of severe neutropenia and other neutropenic complications. Advanced age is a particularly important independent risk factor, since older patients are often treated with lower 
chemotherapy doses to minimize the occurrence of neutropenic complications.

In the present study the majority of the studied patients were non -smokers and this was in the same line with O'Malley et al., (2013), Mahmoud \& Zaki (2015) \& Ibrahim et al., (2016) who reported that never smokers had increased neutropenia versus current smokers with different tumor types including breast, lung, pancreatobiliary, or other unknown primary cancer.

Eleonora et al., (2014) \& Mohamed., (2015) concluded from their work in medical oncology department that myelo-suppressive chemotherapy is commonly associated with neutropenia; the most affected patients with neutropenia were non smokers, females and elderly patient.

\section{Medical data}

This study showed that the most common type of cancer in the studied patients was Acute Myeloid Leukemia and this come in the line with Lyman et al., (2003) \& Khalil et al., (2013) who reported that patients with hematologic malignancies are at higher risk for neutropenia than patients with solid tumors because of the action disease process as well as the severity of the chemotherapy that is required.

This study revealed that the common stage of cancer in the studied group was (stage 4) and this agreed with Lyman et al., (2005), Lyman, (2014) \& El Sayed et al., (2014) who reported that both advanced disease and uncontrolled cancer were significant predictors of hospitalization for febrile neutropenia and serious neutropenic complications, including death. Also, this result agreed with Salar et al., (2012) \& Ahmed et al., (2015) who reported that six studies have found advanced disease (higher disease stage or bone marrow involvement) to be a significant predictor of febrile neutropenia. These studies performed in various cancers, including Non Hodgkin Lymphoma, breast, ovarian, lung, colorectal, and prostate cancer.

Current study concluded that, the majority of the studied patients were from rural area, this may be one cause of the advanced cancer stage in large numbers among the studied patient.

The result of the current study noticed the presence of chronic illness with patients complained from neutropenia and most of these illnesses were cardiovascular disease and this was in line with Kuderer et al., (2004), Yakoot et al., (2010), \& Said et al., (2017) who revealed that the presence of comorbid conditions with cancer has been shown to increase the risk for neutropenia and its infectious complications. Renal disease and heart disease have been shown to increase the risk for febrile neutropenia. Such as hypertension, chronic obstructive pulmonary disease, pneumonia, prior fungal infection, and sepsis have been shown to increase the risk for serious neutropenic complications, including prolonged hospitalizations for febrile neutropenia and death.

As regard medication use with neutropenia the present study revealed that more than half of the studied group used antibiotics and Granulocyte colony-stimulating factors (G-CSF) as a treatment at the onset of admission and this agreed with National Chemotherapy Advisory Group (NCAG, 2015) \& Hashiguchi et al., (2015) recommendation that ensures the use of broad-spectrum antibiotics as firstline antibiotics in all cases. Also Crawford et al., (2011) \& Ahmed, (2017) stated that in many cases, G-CSFs are administered to patients with malignancy to prevent such events.

ECOG Performance Status: Was developed by (the Eastern Cooperative Oncology Group)Oken et al., (1982) this study revealed that more than half of the studied patients located in grade " 0 " full active, able to carry on all pre disease performance without restriction, this finding disagreed with Voog et al., (2000), Lakhanpal (2015) \& Wai \& Shirley, (2015) who reported that three studies have shown that, in addition to age, poor performance status is a significant risk factor for chemotherapy- induced neutropenia. The finding of this study was similar to Nirenberg et al., (2006), \& the National Comprehensive Cancer Network (NCCN) guideline update (2011) when they indicated that poor performance status was not clearly identified as a risk factor for febrile neutropenia.

\section{Patient's knowledge about neutropenia}

The current study revealed a lack of patients' knowledge related to chemotherapy induced neutropenia (CIN) at baseline where mostly had unsatisfactory knowledge levels. However, post applying the designed nursing teaching protocol the studied patients achieved significant improvements in knowledge. This result agreed with Hussein and Shehata (2016). Also researchers from the Waukesha Memorial Hospital in Wisconsin Finkler et al., (2003) issued a survey to 79 oncology patients to assess their knowledge and understanding of chemotherapy induced neutropenia (CIN) and their results indicated that more than half of patients did not know when to contact their physician or oncology nurse and approximately one-third of their patients didn't know infection signs and symptoms. Also around half of them could not describe self-care measures where this result also agreed with Abd Elall et al., (2014).

The researcher noticed that it is necessary for the patients undergoing chemotherapy to detect early as possible of chemotherapy induced neutropenia (CIN) in order to avoid the development of life-threatening 
infections, a patient's role, however, is largely dependent upon the information they receive from oncology nurses or physicians.(Mahmoud \& Zaki, 2015) \& (Teleb \& Mohamed, 2016)

Best et al., (2011) \& Whitlock, (2018) added that the importance of prompt check of abnormal body temperature should be emphasized specially for patients receiving myelo-suppressive chemotherapy and initiating antibiotic therapy in a timely manner is effective in treat febrile neutropenia because the any delay in treatment may lead to highly risk for sepsis and death. Also Meyerhardt et al., (2004) \& Wai \& Shirley, (2015) mentioned that a lack of knowledge was one of the patient-related variables which can be eliminated through the education program.

\section{Complications of neutropenia patients}

The results of recent study represented that about two thirds of the sample had respiratory infection and about one third of the studied patients had gastrointestinal disorder pre application of designed nursing teaching protocol. This was in line with Nirenberg, (2006) \& Ngo-Matip et al., (2015) who stated that the digestive system including oral cavity, esophagus, colon and rectum are the major body parts of infection during neutropenia. Chemotherapy side effects are eutropenic enterocolitis or typhlitis is a severe form of mucosal barrier injury, the respiratory tract, mainly sinuses and lungs, is a common site of infection during neutropenia.

During a short period of neutropenia less than 7 days, pneumonia and sinusitis are usually caused by common respiratory pathogens. The skin including the catheter-site can be a major source of severe infections during neutropenia. Also, this agreed with Ramphal, (2004) \& Hanan et al., (2014) who stated that infections occur in $20 \%-30 \%$ of febrile episodes. The intestinal tract, lung, and skin are the common sites of tissue-based infection. Bacteremia occurs in $10 \%-25 \%$ of all patients, with most episodes occurring in the setting of prolonged or profound neutropenia.

\section{Conclusion}

In light of the existent study finding, it is concluded that there were a highly statistically significant differences between before and after the designed nursing teaching protocol application in all items of knowledge assessment sheet. Likewise there were a highly statistically significant differences between the studied patients' complications of neutropenia before and after application of the designed nursing teaching protocol regarding.

\section{Recommendation}

\section{The study recommended that}

1. Oncology patients undergoing chemotherapy and complaining from neutropenia are critical patients, so they need for qualified nursing staff for caring with them.

2. Each patient undergoing chemotherapy should have the designed nursing teaching protocol Arabic booklet about neutropenia.

3. Powerful substantial tools also patients, families, and healthcare workers' health training programs are important for incite change and correspondence about conceivably dangerous indications related with neutropenia.

\section{References}

1. Abd El- All A., Mohamad A., \& sayed A., (2014): "Esophagogastroduodenoscopy": Impact of a designed nursing teaching protocol on nurse's performance and patient's outcome. J Am Sci, 10(10):56-65].

2. Ahmed G., Muhammad Z., Abd-Elateef M., \& Ghanem H., (2015): Coronary artery bypass grafting" Effect of developing and implementing Nursing Care Standards on patient's outcome, J Am Sci;11(7):181-188].(ISSN:15451003)http://www.jofamericanscience.org. 23

3. Ahmed, S., Soliman, K., \& Mohamed, H., (2017): Effects of Nursing Guidelines on Pain, Hemodynamic State and Pulmonary Complications after Thoracotomy, IOSR Journal of Nursing and Health Science (IOSR-JNHS), eISSN: 2320-1959.p- ISSN: 2320-1940 Volume 6, Issue 4 Ver. VII. (Jul. -Aug .2017), PP 56-65 www.iosrjournals.org

4. Best J., Frith K., Anderson F., Rapp C., \& Rioux L., (2011): Implementation of an evidence-based order set to impact

5. Crawford J., Allen J., Armitage J., Blayney D., \& Cataland S., (2011): Myeloid growth factors. J Natl Compr Canc Netw, Pp: 9:914932.

6. Desoky A., Mohamed M., Khhalil M., \& Ahmed A., (2014): Impact of a Designed Nursing Teaching Protocol on Quality of Life of Patients with Chronic Lower Limb Ischemia at Assiut University Hospital, Journal of Education and Practice, Vol.5, No.31, P.P. 89-99

7. Eleonora C., Patrizia D., Rafael P., Luisa M., Maria P., Giovanni Z., \& Giovanni C., (2014): Impact of Severe Neutropenia and Other Risk Factors on Early Removal of Implanted Central Venous Catheter (ICVC) in ChildrenWith Hematologic Malignancies, Journal of Pediatric Hematology/Oncology, Volume 36 - 
Issue 7 - $\mathrm{p}$ 541-544, doi: 10.1097/MPH.0000000000000158

8. Elsayed N., Ahmed E., \& Elhamid M., (2014): The Expected Role of Triage Nurse in Emergency Reception of a University Hospital, in Egypt , Journal of Biology, Agriculture and Healthcare, Vol.4, No.16, P.P. 69-79

9. Finkler J., Rapp C., \& Johnston M., (2003): Neutropenia in oncology patients, standardizing an educational approach and measuring outcomes. Proceedings from the 2003 annual congress of the Oncology Nursing Society.

10. Gerges N., (2018): Primary Prevention of Genetic Disorders among Secondary School Students in a Rural Area, Faculty of Nursing , Benha University, available at: http://benha.academia.edu/naglagerges)

11. Hashiguchi Y., Kasai M., Fukuda T., Ichimura T., Yasui T., \& Sumi T., (2015): Chemotherapy-induced neutropenia and febrile neutropenia in patients with gynecologic malignancy, 26(10), P.P. 1054-1060. Published online $2015 \quad$ Sep 29. doi: 10.1097/CAD.0000000000000279

12. Hawley E., Loney M., \& Wiece M., (2011): Development of tools and processes to improve treatment times in patients with febrile neutropenia. Clinical Journal of Oncology Nursing, Pp: 15: 53-56.

13. Hussein A., \& Shehata G., (2016): Effect of Nursing Teaching Protocol on quality of life for Patients with Parkinson's Disease. Life Sci J 13(4):105-111]. ISSN: 1097-8135 (Print) / ISSN: 2372-613X

(Online). http://www.lifesciencesite.com. 11. doi: $10.7537 /$ marslsj13041611

14. Ibrahim, R., Abd-Allah, P., Arafa, P., \& Mohammed, S., (2016): Effect of Nursing Care Standards on Nurses Perfomance Regarding Caring for Patients with Cardiac Arrhythmias., Faculty of Nursing, Benha University, thesis of Doctoral Degree in Medical- Surgical Nursing.

15. Khalil S., Mohammad A., Ez El-Deen E., And Ahmed M., (2013): Impact of Implementing A Designed Nursing Intervention Protocol on Nurses' Knowledge and Practice Regarding Patients Undergoing Blood Transfusion, Med. J. Cairo Univ., Vol. 81, No. 2, June: 163-171

16. Kuderer N., Dale D., \& Crawford J., (2004): The impact of febrile neutropenia in hospitalized cancer patients: morbidity, mortality, and cost. Proc Am Soc Clin Oncol Pp: 23:529.

17. Lakhanpal V., (2015): approach to febrile neutropenia, Health \& Medicine, available https://www.slideshare.net/vikaslakhanpal940/fe brile-neutropenia-53793323
18. Lustberg M., (2012): Management of Neutropenia in Cancer Patients, Pp: 10-12: 825826.

19. Lyman G., Abella E., \& Pettengell R., (2014): Risk factors for febrile neutropenia among patients with cancer receiving chemotherapy: A systematic review, Critical Reviews in Oncology/Hematology, Volume 90, Issue 3, June 2014, P.P. 190-199 https://doi.org/10.1016/j.critrevonc.2013.12.006.

20. Lyman G., Crawford J., Dale D., chen H., Agboola O., \& Lininger L., (2014): Clinical prediction models for febrile neutropenia (FN) and relative dose intensity 9RDI) in patients receiving adjuvant breast cancer chemotherapy [abstract 1571]. Pp:20:394a

21. Lyman G., Dale D., \& Crawford J., (2003): Incidence and predictors of low dose-intensity in adjuvant breast cancer chemotherapy: a nationwide study of community practices. J Clin Oncol Pp: 21:4524-4531.

22. Lyman, G., Lyman, C., Agboola, O., \& ANC Study Group. (2005): Risk models for predicting chemotherapy-induced neutropenia. The oncologist, 10(6), 427-437.

23. Mahmoud, S., \& Zaki, R., (2015): Internalized Stigma of Mental Illness among Schizophrenic Patients and Their Families (Comparative Study). Journal of Education and Practice, 6(12), 82-98

24. Meyerhardt J., Kwok A., Ratain M., McGovren J., \& Fuchs C., (2004): Relationship of baseline serum bilirubin to efficacy and toxicity of single-agentirinotecan in patients with metastatic colorectal cancer. J Clin Oncol, Pp: 22:1439-46.

25. Mohamed, N., (2015): Effect of Designed Nursing Protocol on Nurse's Knowledge and Practice Regarding Chemotherapy. Med. J. Cairo. Univ, 83(2), 209-216.

26. National Cancer Institute (NCI) US Department of Health and Human Services, National Institutes of Health, (2010): Common Terminology Criteria for Adverse Events (CTCAE) Version 4.03.

27. National Chemotherapy Advisory Group NCAG., (2015): Chemotherapy services in England: ensuring quality, safety: a report from the National Chemotherapy Advisory Group. UK: National Chemotherapy Advisory GroupAnti-Cancer Drugs, Vol. (26) No. (10)

28. Ngo-Matip M, Pieme C., Azabji-Kenfack M., Moukette B., Korosky E., Stefanini P., Ngogang J., \& Mbofung C., (2015): Impact of daily supplementation of Spirulina platensis on the immune system of naïve HIV-1 patients in 
Cameroon: a 12-months single blind, randomized, multicenter trial, Nutrition Journal14:70, https://doi.org/10.1186/s12937015-0058-4

29. Nirenberg, A., Bush, A., Davis, A., \& Friese, C., (2006): November: Neutropenia: state of the knowledge part I. In Oncology Nursing Forum (Vol. 33, No. 6, p. 1193). Oncology Nursing Society.

30. O'Malley M., Healy P., Daignault S., \& Ramnath N., (2013): Cigarette Smoking and Gemcitabine-Induced Neutropenia in Advanced Solid Tumors. Oncology. vol (85) issue(4) Pp:216-222.

31. Oken M., Creech R., Tormey D., Horton J., Davis T., \& McFadden E., (1982): Toxicity and response criteria of the Eastern Cooperative Oncology Group. Am J Clin Oncol. Pp: 5:64955. [PubMed]

32. Ramphal R., (2004): Changes in the etiology of bacteremia in febrile neu-tropenic patients and the susceptibilities of the currently isolated pathogens. Clin Infect Dis., 39(Suppl 1) pp: S25-31.

33. Rasmy A., Amal A., Fotih S., \& Selwi W., (2016): Febrile Neutropenia in Cancer Patient: Epidemiology, Microbiology, Pathophysiology and Management. J Cancer Prev Curr Res 5(3): 00165. DOI:10.15406/jcpcr.2016.05.00165)

34. Ropka M., \& Padilla G., (2007): Assessment of neutropenia-related quality of life in a clinical setting, Oncol Nurs Forum, Pp: 34: 403-409.

35. Said N., Sheble A., \& Mohammed H., (2017): Comparison between Uses of Chlorhexidine Gluconate versus Povidone Iodine for Skin Preparation to Prevent Infection after Cardiothoracic Surgery, IOSR Journal of Nursing and Health Science (IOSR-JNHS) eISSN: 2320-1959.p- ISSN: 2320-1940 Volume 6, Issue 2 Ver. IIm PP 72-80 www.iosrjournals.org

36. Salar A., Haioun C., Rossi F., Duehrsen U., \& Pettengell R., (2012): The need for improved neutropenia risk assessment in DLBCL patients receiving $\mathrm{R}-\mathrm{CHOP}-21$ : findings from clinical practice. LeukRes Pp: 36:548-53.

37. Schelenz S., Giles D., \& Abdallah S., (2012): Epidemiology, management and economic impact of febrile neutropenia in oncology patients receiving routine care at a regional $\mathrm{UK}$ cancer centre. Ann Oncol vol( 23) issue (7) Pp:1889-1893.

38. Supportive, P., \& Board, P., (2016): Oral Complications of Chemotherapy and Head/Neck Radiation (PDQ®),National cancer institute , at the National Institutes of Health, available at: https://www.cancer.gov/aboutcancer/treatment/side-effects/mouth-throat/oralcomplications-hp-pdq

39. Teleb O.., Mohamed B., (2016): Effectiveness of a Nursing Intervention Protocol for Chemotherapy Induced Neutropenia: Nurses and Patients' Related Outcome. Ann Nurs Pract 3(1): P.P.1038.

40. Villafuerte Gutierrez P., Villalon L., Losa J., \& Henriquez Camacho C., (2014): Treatment of Febrile Neutropenia and Prophylaxis in Hematologic Malignancies, A Critical Review and Update, Advances in Hematology Pp: 9.

41. Voog E., Bienvenu J., \& Warzocha K., (2000): Factors that predict chemotherapy-induced myelosuppression in lymphoma patients: role of the tumor necrosis factor ligand-receptor system. J Clin Oncol Pp: 18:325-331.

42. Wai C., \& Shirley S., (2015): Effect of an education program on knowledge, self-care behavior and handwashing competence on prevention of febrile neutropenia among breast cancer patients receiving Doxorubicin and Cyclophosphamide in Chemotherapy Day Centre, Asia Pac J Oncol Nurs, 2(4), P.P. 276288. doi: 10.4103/2347-5625.167232

43. Weycker D., Barron R., Kartashov A., Legg J., \& Lyman G., (2014): Incidence, treatment, and consequences of chemotherapy-induced febrile neutropenia in the inpatient and outpatient settings. J Oncol Pharm Pract. , Pp: 20: 190-198.

44. Yakoot M., Salem A., \& Omar A., (2010): Clinical efficacy of farcosolvin syrup (ambroxol-theophylline-guaiphenesin mixture) in the treatment of acute exacerbation of chronic bronchitis, International Journal of Chronic Obstructive Pulmonary Disease, vol,(5),P.P. $251-256$,

DOI https://doi.org/10.2147/COPD.S10981) 